\title{
Evaluation of biomarkers in oyster larvae in natural and polluted conditions
}

\author{
G. Damiens ${ }^{\mathrm{a}}$, E. His ${ }^{\mathrm{b}}$, M. Gnassia-Barelli ${ }^{\mathrm{a}}$, F. Quiniou ${ }^{\mathrm{c}}$ and M. Roméo ${ }^{\mathrm{a}^{*}}$ \\ a UMR 1112INRA-UNSA R.O.S.E., Biology Lab ROSE, Faculté des Sciences, BP 71, 06108 Nice Cedex 2, \\ France \\ ${ }^{\mathrm{b}}$ IFREMER, Station d'Arcachon, 1 quai du commandant Silhouette, 33120 Arcachon, France \\ ${ }^{\mathrm{c}}$ DEL/PC, IFREMER, Centre de Brest, BP 70, 29280 Plouzané, France \\ *romeo@unice.fr Tel./fax: +33 492076822.
}

\begin{abstract}
Crassostrea gigas D-shaped larvae were subjected to different conditions of temperature and salinity for $24 \mathrm{~h}$ and four biomarkers (acetylcholinesterase (AChE) activity, thiobarbituric acid reactive substances (TBARS) levels, glutathione S-transferase (GST) and catalase (CAT) activities) were measured. AChE activity decreased when salinity increased from 25 to 30 and 35 psu at 20 and $25{ }^{\circ} \mathrm{C}$. Temperature did not seem to have an influence on AChE activity. TBARS levels increased as a function of salinity when the temperature was maintained at $20^{\circ} \mathrm{C}$, whereas at $25^{\circ} \mathrm{C}$ no effect of salinity could be observed. Variations in GST and CAT activities were not significant with salinity and temperature except that catalase activity was higher at $25{ }^{\circ} \mathrm{C}$ than at $20^{\circ} \mathrm{C}$. Exposure experiments were conducted at $23^{\circ} \mathrm{C}$ and 30 psu with carbofuran (100 and $\left.1000 \mu \mathrm{g} / \mathrm{l}\right)$ and malathion (100 and 300 $\mu \mathrm{g} / \mathrm{l})$. There was an inhibition of AChE activity with carbofuran, and a toxic effect shown by an increase in TBARS levels counteracted by increases in GST and CAT activities which protected the larvae. When two pairs of adults producing larvae were taken into consideration, significant differences in biomarker levels were noted between the larval offspring of each pair. Malathion induced a decrease in AChE activity and an increase in CAT activity.
\end{abstract}

Keywords: Biomarker; Mollusc larvae; Crassostrea gigas; Abiotic factors; Carbofuran; Malathion 


\section{Introduction}

Marine pollution has been traditionally documented in terms of chemical concentrations of contaminants; however these measurements did not provide estimations of the deleterious effects upon living organisms and are now complemented with biological criteria, and especially with the measurement of biomarkers. Biomarkers consist of biochemical and/or physiological changes in organisms exposed to contaminants, and thus represent initial responses to environmental perturbations and contamination (McCarthy and Shugart, 1990; Bengtson and Henshel, 1996; Roy et al., 1996). They are generally regarded as more sensitive than bioindicators at higher levels of the biological hierarchy (Stegeman et al., 1992). In contrast to the simple measurement of contaminants accumulating in body tissues, biomarkers can offer a more complete and biologically more relevant information on the potential impact of contaminants on the health of organisms (Van der Oost et al., 1996). Different categories of biomarkers have been identified, e.g. biomarkers of exposure and response, or general and specific biomarkers, according to de Lafontaine et al. (2000). EROD activity (ethoxyresorufin O-deethylase) is widely used as an exposure biomarker of organic contaminants in biomonitoring programs. A large number of field studies have been carried out during the last 20 years. Various biomarkers have been measured in different groups of aquatic organisms, particularly in fish and some bivalve molluscs. In many cases, piscine EROD activities or CYP1A protein levels have been correlated with environmental levels of CYP1A-inducing chemicals such as PAHs or PCBs. Nevertheless, one cannot always expect a linear doseresponse relationship between the concentration of certain chemicals and CYP1A content and/or activity in the natural environment, where a mixture of both inducers and inhibitors of CYP1A may act simultaneously (Pluta, 1993). Finally, other factors such as temperature, season or sexual hormones can also modulate the response of the CYP1A system in fish 
(Stegeman and Hahn, 1994). Thus, caution is required when interpreting isolated biomarker data. In this respect, the measurement of biomarkers in bivalve larvae, which are not subjected to sexual variations, contrary to juveniles and adults, may constitute a useful tool to assess the modifications of the environment due to anthropogenic influences, in an early manner. Indeed, the first developmental stages of bivalves have been shown to be highly sensitive to micropollutants. Embryos and larvae of oysters of the genus Crassostrea and mussels of the genus Mytilus have been proposed as sentinel organisms for marine ecotoxicological tests (Wiseley and Blick, 1967; Granmö, 1972; Stebbing et al., 1980; His et al., 1999a). The use of this biological material for evaluating early signals of pollution such as biomarkers may respond to the challenges faced in aquaculture and in risk assessment.

Very few papers deal with biomarker measurement in bivalve mollusc larvae or embryos. Pavicic et al. (1985, 1994) have shown that embryos and larvae of Mytilus galloprovincialis were able to induce synthesis of metallothioneins (MT), considered a biomarker of exposure to metals, in the presence of metals such as cadmium, zinc and mercury. The same phenomenon was observed by Ringwood and Brouwer (1995) and Roesijadi et al. (1996), particularly in C. gigas embryos. Nevertheless the above-mentioned authors used unrealistically high experimental concentrations. However, induction of $\mathrm{MT}$ in $M$. galloprovincialis larvae exposed to naturally contaminated sediments has also been observed recently (Geffard et al., 2002).

Biomarkers are biological parameters, known to vary in response to environmental pollutants, and which are involved in the normal metabolism of organisms. Biotic factors such as sex, sexual maturity, size and weight and abiotic factors (season, temperature, salinity) may change activities or levels of biochemical biomarkers whatever the contamination of the environment. The biotic factors do not need to be taken into consideration when using $24 \mathrm{~h}$ 
old larvae. Nevertheless, the use of bivalve larvae does not eliminate the effects of temperature and salinity.

In the present paper, C. gigas D-shaped larvae were subjected to different conditions of temperature and salinity for 24 hours and four biomarkers (AChE activity, TBARS levels, GST and CAT activities) were measured. Following the results obtained, some exposures were also performed with the effect of two well-known pesticides on $C$. gigas larvae, carbofuran, which is a carbamate and malathion, which is an organophosphorous compound. The choice of biomarkers measured in larvae of $C$. gigas was decided for several reasons. GST isoforms are involved in the metabolism of organochlorine pesticides (Fitzpatrick et al., 1997) and consequently have begun to be used as biomarkers of these substances and PCBs in molluscs (Fitzpatrick et al., 1997; Hoarau et al., 2001) because EROD, as an exposure biomarker of organic compounds, does not give satisfactory responses in these animals (Cajaraville et al., 2000). CAT activity (EC 1.11.1.6), although not responding specifically to a group of contaminants but to oxidative stress, was also used in this work. This is because the primary defense against oxidative damage consists of some low molecular weight compounds (vitamins A, C, and E, glutathione) and antioxidant enzymes such as CAT, which has been studied in molluscs (Pellerin-Massicotte, 1997). Additionally, a marker of oxidative stress, the thiobarbituric acid reactive substances, termed as TBARS, was also measured as reflecting the state of membrane lipid peroxidation (Knight et al., 1988). AChE activity, inhibited by the presence of organophosphorus compounds and carbamates, is considered as an exposure biomarker to these substances (Galgani and Bocquené, 1989) and consequently has been used in coastal biomonitoring programs (Escartin and Porté, 1997; Stein et al., 1998; Mora et al., 1999). 


\section{Materials and methods}

\subsection{Larvae production}

Mature oysters (C. gigas) were conditoned in a hatchery, and then induced to spawn by thermal stimulation (His et al. 1997, 1999b). Females in the laying process were isolated in ca $1 \mathrm{~L}$ of sea water, whilst spawning males were put in a small amount (ca $100 \mathrm{~mL})$ of sea water, to obtain a sperm-dense solution. The oocytes and sperm of different oysters were observed under an inverted microscope, and the most reproductive pair (regular oocytes and very mobile spermatozoa) was selected for the experiment. The oocytes were fertilized by the sperm-dense solution (5 to 7 spermatozoa per 1 oocyte). Fifteen minutes after fertilization, embryos were counted and placed into $2 \mathrm{~L}$ beakers (60,000 fertilized eggs/L) filled with 0.2 $\mu \mathrm{m}$ filtered sea water (two replicates per treatment and 6 beakers per sample). Fertilized eggs from one female and one male were used (duplicate experiments) to minimize genetic variability (Stebbing et al., 1980) in order to obtain a significant biomarker response. In some experiments, the effect of parents on the biochemical responses was tested using two adult couples.

\subsection{Effect of temperature and salinity}

Two temperatures $\left(20^{\circ} \mathrm{C}\right.$ and $\left.25^{\circ} \mathrm{C}\right)$ and three salinities $(25,30,35$ p.s.u.) for each temperature were used. These temperatures and salinities were those found along the French Atlantic coast where oysters are cultivated. Embryos were incubated at the chosen temperature and salinity for $24 \mathrm{~h}$ in the dark until D-larvae were obtained (His et al., 1997). After incubation, larvae were recovered through a sieve $(32 \mu \mathrm{m})$ and counted. They were 
rinsed with homogenization buffer (as described below), freeze-dried and stored for biochemical analysis.

\subsection{Carbofuran and malathion exposures}

With regard to the previous results from the salinity and temperature experiments, exposures were carried out with two pesticides: carbofuran (carbamate) and malathion (organophosphorus compound) at an average salinity (30.0 \pm 0.5 p.s.u.) and an average temperature $\left(23 \pm 1^{\circ} \mathrm{C}\right)$. The pollutant concentrations were: 100 and $1000 \mu \mathrm{g} / \mathrm{L}$ of carbofuran and 100 and $300 \mu \mathrm{g} / \mathrm{L}$ of malathion. These pollutants were dissolved in water for stock solutions and then in seawater. The concentrations were chosen because previous toxicity tests performed with M. galloprovincialis larvae indicated that carbofuran was less toxic than malathion with an EC50 of $5.46 \mathrm{mg} / \mathrm{L}$ compared to that of malathion which was $2.19 \mathrm{mg} / \mathrm{L}$. As in the first experiments with salinity and temperature, fertilized eggs were introduced into the medium with different concentrations of pesticide for $24 \mathrm{~h}$. A first experiment was performed with carbofuran, and a second experiment with carbofuran was duplicated by using two groups of larvae from two adult couples (couple A and couple B). An exposure experiment was also performed with malathion.

\subsection{Toxicity tests}

Fertilized eggs were incubated with increasing concentrations of $\mathrm{CuSO}_{4}(0,20,40,60,80$ $\mu \mathrm{g} \mathrm{CuSO} / \mathrm{L}$ ) for $24 \mathrm{~h}$ to determine the percentage of abnormal larvae at each concentration (3 replicates per concentration). The test gave an $\mathrm{EC} 50\left(\mathrm{CuSO}_{4}\right.$ concentration producing $50 \%$ of 
abnormal larvae), which allowed the estimation of the physiological status of the larvae. The toxic level was considered to be reached at ca $30 \mu \mathrm{g} \mathrm{CuSO}_{4} / \mathrm{L}$ (Quiniou et al., 1997).

\subsection{Biochemical analysis}

The larvae were homogenized in a TRIS buffer (TRIS 50 mM, NaCl 150 mM, pH 7.4, 0.1 $\mathrm{mM}$ antiprotease cocktail, $1 \mathrm{mM}$ DTT (dithiothreitol)) in a 1/3 w/v (weight/volume) ratio, using a Potter-Elvehjem glass homogenizer fitted with a teflon pestle. The homogenates were then centrifuged for $25 \mathrm{~min}$ at $9000 \mathrm{~g}$. All procedures were carried out at $0-4{ }^{\circ} \mathrm{C}$. Aliquots of the supernatant (S9 fraction) were frozen at $-80^{\circ} \mathrm{C}$ until analysed. All determinations of enzyme assays, total protein and TBARS levels were performed on S9 fractions.

Total proteins were determined according to Bradford (1976). AChE activity was determined using the Ellman et al. method (1961) adapted to a microplate reader by Galgani and Bocquené (1991). Lipid peroxidation was estimated by the formation of TBARS, which are considered as “malonedialdehyde (MDA)-like peroxide products” (Buege and Aust 1978). TBARS were quantified compared to the MDA absorbance reference $\left(\varepsilon=156 \cdot 10^{3} \mathrm{M}^{-1} \cdot \mathrm{cm}^{-1}\right)$, but results were not expressed as MDA concentrations because TBA can react with a range of chemical compounds (Csallany et al., 1984), but as TBARS levels. GST activities were measured by spectrophotometry at $340 \mathrm{~nm}$, following conjugation of the acceptor substrate 1chloro-2,4-dinitrobenzene (CDNB) with reduced glutathione (Habig et al., 1974). Catalase activities were assayed as described in Clairbone (1985). The variations of absorbance at 240 $\mathrm{nm}$, caused by the dismutation of hydrogen peroxide, were measured as a function of time ( $\varepsilon$ $\left.=40 \mathrm{M}^{-1} \cdot \mathrm{cm}^{-1}\right)$. 


\subsection{Chemical analysis}

\subsubsection{Carbofuran analysis}

The analysis of carbofuran was started by a liquid/solid extraction of $1 \mathrm{~L}$ of culture medium, set at $\mathrm{pH} 3$, followed by elution and concentration to $1 \mathrm{ml}$. The analysis was performed by HPLC coupled to a spectrofluorimetric detector and the detection limit was $0.02 \mu \mathrm{g} / \mathrm{L}$.

\subsubsection{Malathion analysis}

One liter of culture medium was submitted to a liquid/liquid phase extraction by dichloromethane then concentrated to $1 \mathrm{ml}$. The analysis was done by GC/MS. The detection limit was $0.01 \mu \mathrm{g} / \mathrm{L}$. This analysis was realized according to NF EN ISO 12918 norm.

\subsection{Statistics}

ANOVAs were performed with the different salinities at $20^{\circ} \mathrm{C}$ and at $25^{\circ} \mathrm{C}$. When they were significant, pairwise comparisons by Scheffé tests were carried out, significant differences were considered at the 95\% level. For each salinity, Scheffé-test was used to compare the results at 20 and $25^{\circ} \mathrm{C}$.

The experiments with pesticides were carried out with less samples than those abovementioned. The global non-parametric test Kruskal-Wallis was used followed, when significant, by a Mann-Whitney comparison test. 
3. Results

3.1. Effects of salinity and temperature on biomarker levels in C. gigas larvae

The effects of temperature (20 and $25{ }^{\circ} \mathrm{C}$ ) and salinity (25, 30 and 35 p.s.u.) on the response of biomarker in oyster larvae ( $24 \mathrm{~h}$ incubation) are shown in Fig 1a, 1b, 1c, 1d. There are 6 replicates for each condition. 
Fig.1. Biomarker levels (mean value \pm 1 S.E.M.; $\mathrm{n}=6$ in each case) in C. gigas larvae from differing conditions of temperature $\left(20^{\circ} \mathrm{C}\right.$ and $25^{\circ} \mathrm{C}$ ) and salinity (20, 30, 35 p.s.u.) : (a) AChE activity (nmol/min/mg protein) ; (b) TBARS level (nmol/mg protein); (c) GST activity (nmol/min $/ \mathrm{mg}$ protein); (d) CAT activity ( $\mu \mathrm{mol} / \mathrm{min} / \mathrm{mg}$ protein). ANOVAs were performed with the different salinities at $20^{\circ} \mathrm{C}$ and at $25^{\circ} \mathrm{C}$. When ANOVAs were significant, pairwise comparisons by Scheffé tests were carried out, data with the same superscript did not vary significantly at the $95 \%$ level. For each salinity, Scheffé-test was used to compare the results at 20 and $25^{\circ} \mathrm{C}$.

a )

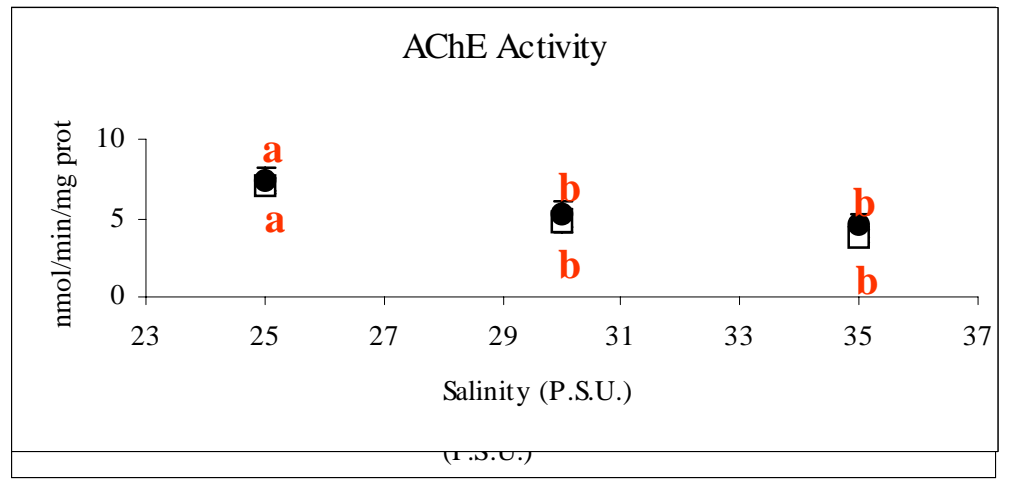

b )

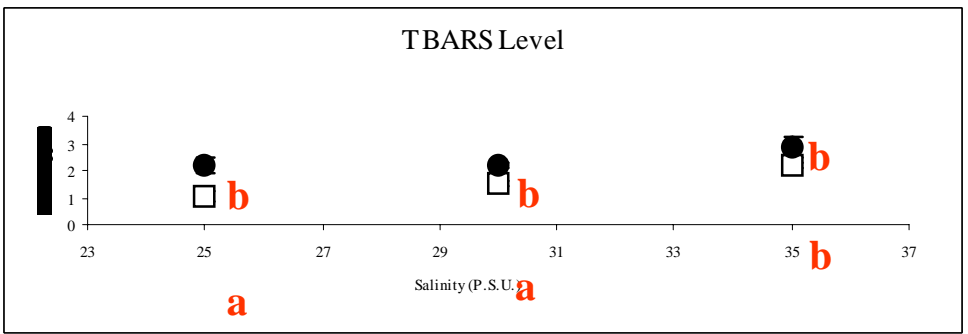

c)

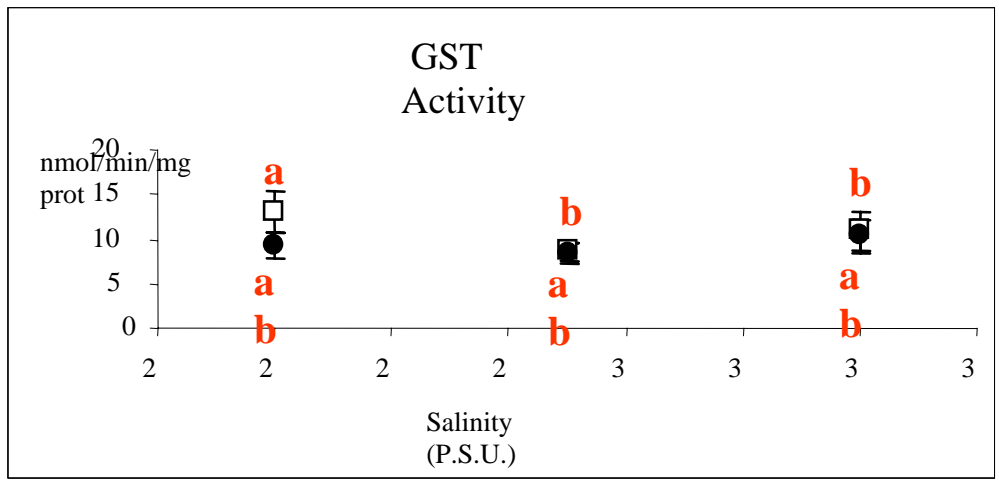

d )

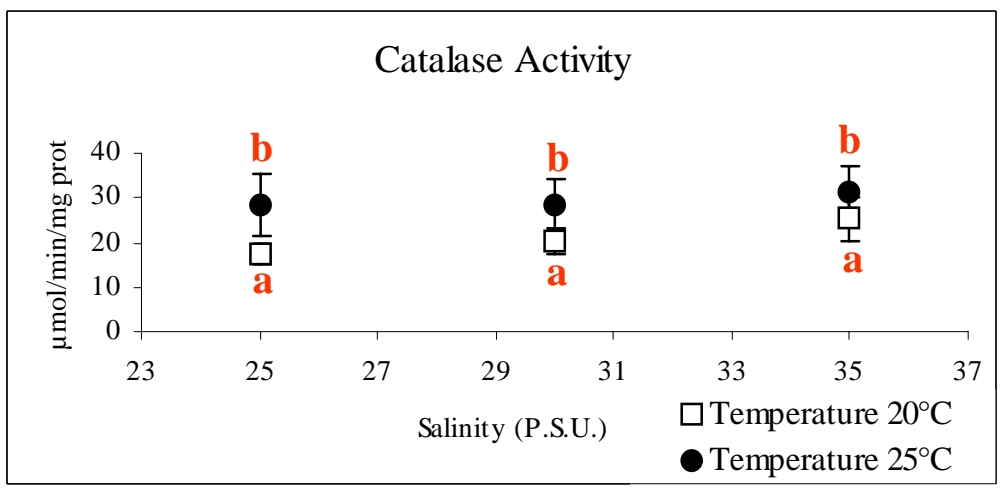




\subsubsection{AChE activity (Fig 1a)}

At $20^{\circ} \mathrm{C}$, AChE activity significantly decreased from $7.39 \pm 1.65$ to $3.83 \pm 1.09$ nmol/min/mg protein from salinities 25 to 35 p.s.u.. Global ANOVA with salinity as a controlled factor was significant $(\mathrm{p}=0.0087, \mathrm{n}=18)$, as well as Scheffé tests between the different groups. At $25^{\circ} \mathrm{C}$, AChE activity also decreased as a function of salinity, from $7.46 \pm$ 1.98 (25 p.s.u.) to $4.23 \pm 1.13 \mathrm{nmol} / \mathrm{min} / \mathrm{mg}$ protein (35 p.s.u.). On the contrary, whatever the salinity, the influence of temperature $\left(20\right.$ or $\left.25^{\circ} \mathrm{C}\right)$ was not significant.

\subsubsection{TBARS levels (Fig 1b)}

At $20^{\circ} \mathrm{C}$, TBARS levels increased as a function of salinity from $1.05 \pm 0.44$ ( 25 p.s.u.) to $2.47 \pm 0.19 \mathrm{nmol} / \mathrm{mg}$ protein (35 p.s.u.). An ANOVA with salinity as a controlled factor was significant ( $\mathrm{p}=0.0015)$, as well as Scheffé tests between TBARS levels at 25 and 30 p.s.u. compared to that at 35 p.s.u.. At $25^{\circ} \mathrm{C}$, TBARS levels tended to increase between 30 and 35 p.s.u. Considering all salinities together, mean global TBARS concentrations were significantly higher (Scheffé test significant at $\mathrm{p}=0.024$ ) at $25^{\circ} \mathrm{C}: 2.27 \pm 0.79 \mathrm{nmol} / \mathrm{mg}$ protein $(n=18)$ than at $20^{\circ} \mathrm{C}: 1.60 \pm 0.72 \mathrm{nmol} / \mathrm{mg}$ protein $(\mathrm{n}=18)$. At each salinity, the level of significant differences between TBARS levels at 20 and $25^{\circ} \mathrm{C}$ is shown in Fig. $1 \mathrm{~b}$.

\subsubsection{GST activity (Fig 1c)}

At $20^{\circ} \mathrm{C}$, GST activity decreased from $172.9 \pm 34.6 \mathrm{nmol} / \mathrm{min} / \mathrm{mg}$ protein at 25 p.s.u. to $87.3 \pm 38.9$ at 30 p.s.u., and then increased to $109.2 \pm 54.5 \mathrm{nmol} / \mathrm{min} / \mathrm{mg}$ protein at $35 \mathrm{p}$. s.u.. ANOVA with salinity as a controlled factor was significant $(\mathrm{p}=0.0011)$, Scheffé test 
demonstrated that, at the lowest salinity, GST activity in larvae was higher than at the other salinities. At $25^{\circ} \mathrm{C}$, there was no variation in GST activity, which was remarkably stable as a function of salinity. Considering all salinities together, the activities were slightly higher at $20^{\circ} \mathrm{C}: 115.0 \pm 57.6 \mathrm{nmol} / \mathrm{min} / \mathrm{mg}$ protein than at $25^{\circ} \mathrm{C}: 93.6 \pm 39.4 \mathrm{nmol} / \mathrm{min} / \mathrm{mg}$ protein but the Scheffé test was not significant.

\subsubsection{Catalase activity (Fig 1d)}

At $20^{\circ} \mathrm{C}$ and at $25^{\circ} \mathrm{C}$ catalase activity was stable as a function of salinity. Considering all salinities together, catalase activities were significantly higher (Scheffé test significant at $\mathrm{p}=$ 0.019 ) at $25^{\circ} \mathrm{C}: 29.40 \pm 15.29 \mu \mathrm{mol} / \mathrm{min} / \mathrm{mg}$ protein than at $20^{\circ} \mathrm{C}: 20.45 \pm 9.62 \mu \mathrm{mol} / \mathrm{min} / \mathrm{mg}$ protein. At each salinity, the level of significant differences between CAT levels at 20 and $25^{\circ} \mathrm{C}$ is shown in Fig. $1 \mathrm{~d}$.

3.2. Pesticide effects on C. gigas larvae

\subsubsection{Carbofuran}

Two experiments were carried out. The results of the first experiment (figure not shown) demonstrated a significant inhibition of acetylcholinesterase activity, which decreased from $8.81 \pm 0.92$ in controls to $2.63 \pm 0.37$ at $100 \mu \mathrm{g} / \mathrm{L}$ and to $1.73 \pm 0.35 \mathrm{nmol} / \mathrm{min} / \mathrm{mg}$ protein at $1000 \mu \mathrm{g} / \mathrm{L}(\mathrm{n}=12$, Kruskal-Wallis significant at $\mathrm{p}=0.0001$, Mann-Whitney test of comparison with controls significant at $\mathrm{p}<0.001$ ). At the highest carbofuran concentration, TBARS levels increased from $0.39 \pm 0.02$ in controls to $0.69 \pm 0.03 \mathrm{nmol} / \mathrm{mg}$ protein at 1000 $\mu \mathrm{g} / \mathrm{L}$ (Kruskal-Wallis significant at $\mathrm{p}=0.0011$, Mann-Whitney test significant at $\mathrm{p}<0.05$ 
between controls and larvae exposed at $1000 \mu \mathrm{g} / \mathrm{L}$ ). GST and catalase activities did not significantly vary in larvae exposed to carbofuran compared to controls .

During the second experiment, toxicity thresholds with copper sulphate were estimated. The toxicity varied according to the considered pair of animals. It reached $40 \mu \mathrm{CuSO}_{4} / \mathrm{L}$ for couple A and $30 \mu \mathrm{g} / \mathrm{L}$ for couple B. These thresholds demonstrated that the larvae from couple A were in better physiological status than those from couple B.

AChE activity decreased only for couple B (Fig. 2a, Kruskal-Wallis test significant at p = $0.01, \mathrm{n}=12$, Mann-Whitney significant at $\mathrm{p}<0.05$ between control larvae and larvae exposed at $100 \mu \mathrm{g} / \mathrm{L}$ ), compared to the corresponding control. TBARS levels did not vary as a function of concentration for both couples compared to the controls (Fig. 2 b). GST activity (Fig. 2c) significantly increased as a function of carbofuran exposure for both couples (Kruskal-Wallis test significant at $\mathrm{p}=0.015$, Mann-Whitney significant at $\mathrm{p}<0.05$ for both of them). As regards catalase activity (Fig 2d), the two couples responded differently, there was an increase for couple $\mathrm{A}$ as the carbofuran concentration increased (Kruskal-Wallis test significant, $\mathrm{p}=$ 0.015, Mann-Whitney significant significant at $\mathrm{p}<0.05$ ), whereas for couple $\mathrm{B}$ catalase activity showed a slight increase at $100 \mu \mathrm{g} / \mathrm{L}$, and sharply decreased at $1000 \mu \mathrm{g} / \mathrm{L}$ (MannWhitney significant at $\mathrm{p}=0.02)$ compared to the controls. The differing levels of biomarker responses with respect to each pair of animals, are particularly noticeable for TBARS levels, CAT and GST activities.

The measurement of the carbofuran concentration in the medium of the first experiment showed an important loss of carbofuran. Indeed, concentrations were less than $0.02 \mu \mathrm{g} / \mathrm{L}$ for the control, $56.20 \mu \mathrm{g} / \mathrm{L}$ instead of the nominal concentration of $100 \mu \mathrm{g} / \mathrm{L}$ and $340.58 \mu \mathrm{g} / \mathrm{L}$ instead of $1000 \mu \mathrm{g} / \mathrm{L}$. 
Fig. 2. Biomarker levels (mean value \pm 1 S.E.M.; $\mathrm{n}=6$ in each case) in $C$. gigas larvae from two couples (A and B), in different concentrations of carbofuran (0, 100 and $1000 \mu \mathrm{g} / \mathrm{L}$ ); (a) AChE activity (nmol/min/mg protein); (b) TBARS level (nmol/mg protein); (c) GST activity (nmol/min $/ \mathrm{mg}$ protein); (d) CAT activity ( $\mu \mathrm{mol} / \mathrm{min} / \mathrm{mg}$ protein). When Kruskal-Wallis was significant, Mann Whitney tests were performed * show significant differences compared to the corresponding controls at $\mathrm{p}<0.05$ level.

a )

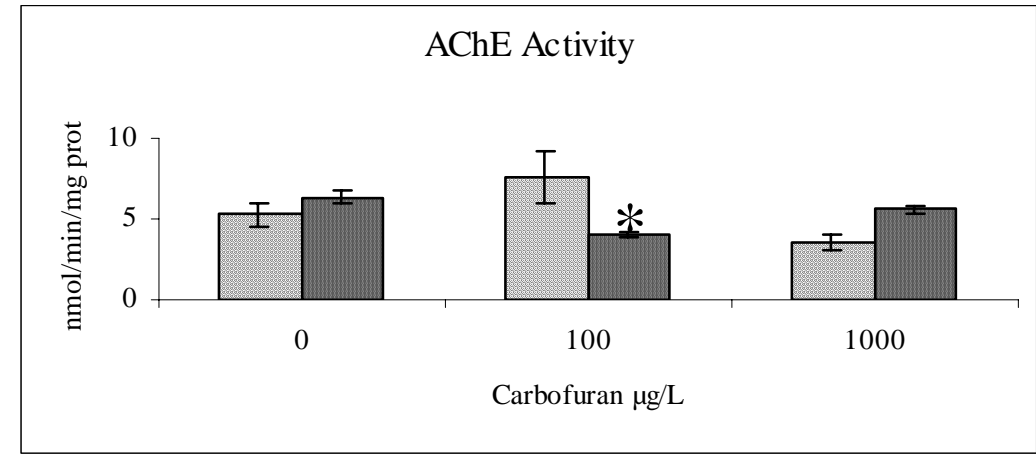

b )

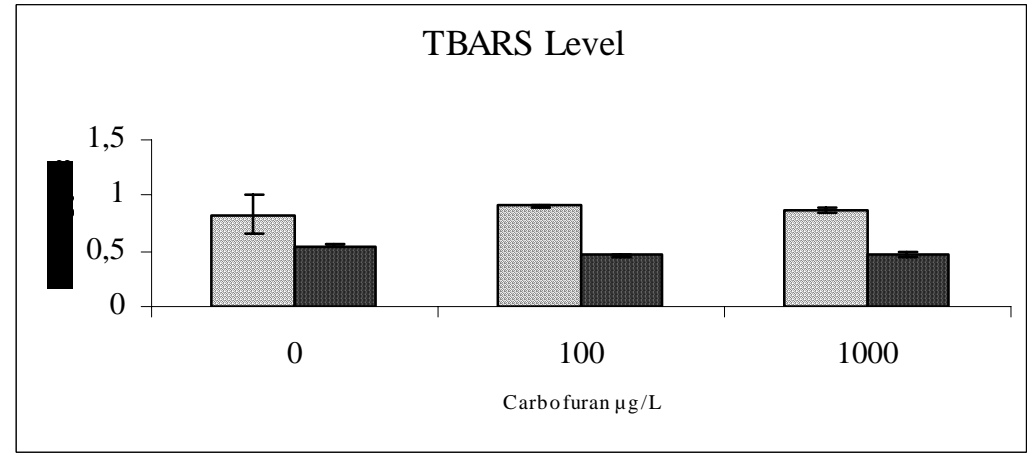

C)

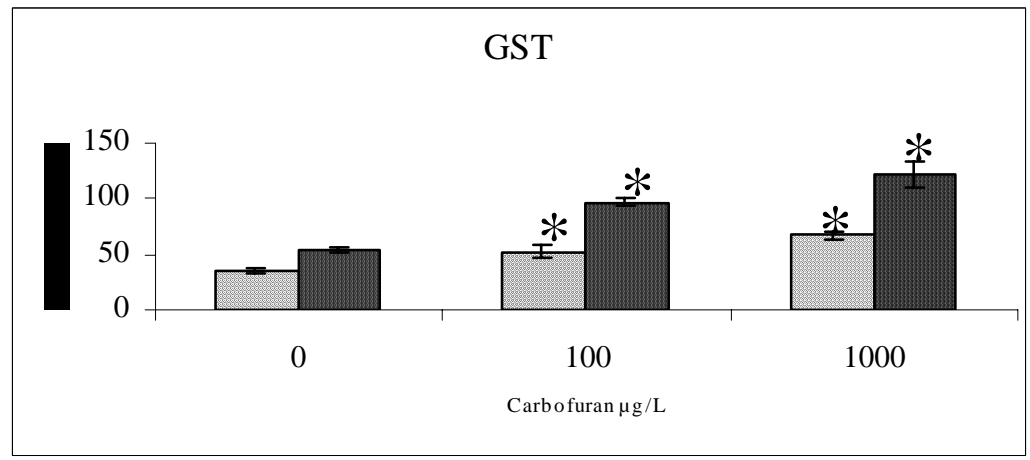

d)

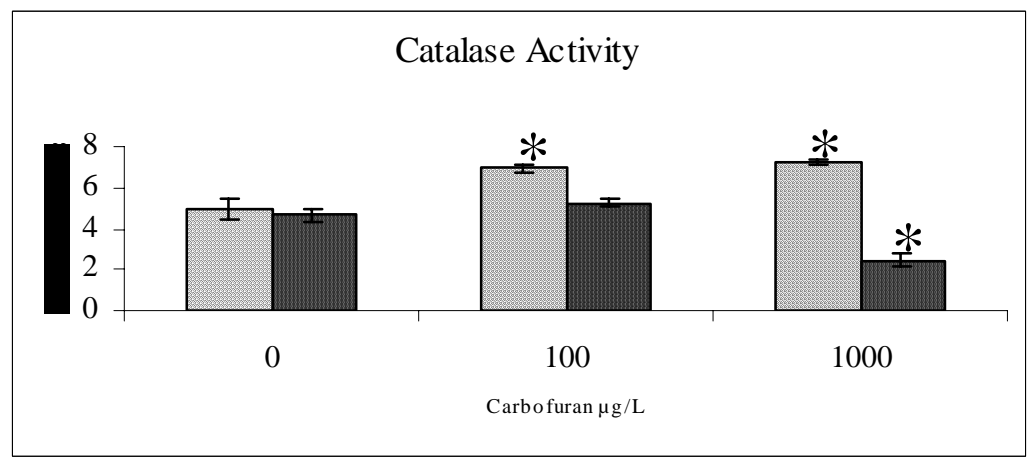




\subsubsection{Malathion}

Two couples were studied but only larvae from couple A (toxicity threshold $=40 \mu \mathrm{g}$ $\mathrm{CuSO}_{4} / \mathrm{L}$ ) had a good physiological status for measuring biomarker levels, (larvae from couple B presented a toxicity threshold of $<20 \mu \mathrm{g} \mathrm{CuSO}_{4} / \mathrm{L}$ ). The results of biomarkers measured in couple A are shown in Fig 3. AChE activity (Fig. 3a) decreased from $7.75 \pm 0.35$ for the controls to $6.17 \pm 0.07$ at $100 \mu \mathrm{g} / \mathrm{L}$ and $5.79 \pm 0.24 \mathrm{nmol} / \mathrm{min} / \mathrm{mg}$ protein at $300 \mu \mathrm{g} / \mathrm{L}$ (Kruskal-Wallis significant at $\mathrm{p}<0.0001, \mathrm{n}=12$, Mann-Whitney test of comparison with controls significant at $\mathrm{p}<0.0005$ for both malathion concentrations). A slight but non significant decrease of TBARS levels was observed (Fig. 3b). In the same way, GST activity (Fig. 3c) did not significantly vary between control and exposed larvae. The CAT measurement showed an increase of activity for the highest malathion concentration, from $20.17 \pm 0.49$ for the controls to $23.12 \pm 0.97 \mu \mathrm{mol} / \mathrm{min} / \mathrm{mg}$ protein at $300 \mu \mathrm{g} / \mathrm{L}$ (KrusalWallis, $\mathrm{n}=12$, significant at $\mathrm{p}=0.0115$, Mann-Whitney test between controls and larvae exposed at $300 \mu \mathrm{g} / \mathrm{L}$ significant at $\mathrm{p}<0.05)$.

The measured concentrations of malathion in the medium were lower than the nominal concentrations. Indeed, malathion concentration was less than $0.01 \mu \mathrm{g} / \mathrm{L}$ for control, $66 \mu \mathrm{g} / \mathrm{L}$ instead of $100 \mu \mathrm{g} / \mathrm{L}$ and $228 \mu \mathrm{g} / \mathrm{L}$ instead of $300 \mu \mathrm{g} / \mathrm{L}$.

\section{Discussion}

Few papers have dealt with biochemical biomarkers in bivalve larvae, thus the results that we have obtained will be compared with what is known for adult molluscs or other marine invertebrates. 
Fig. 3. Biomarker levels (mean value \pm 1 S.E.M.; $n=4$ in each case) in C. gigas larvae, in different concentrations of malathion (0, 100 and $300 \mu \mathrm{g} / \mathrm{L}$ ); (a) AChE activity (nmol/min/mg protein); (b) TBARS level (nmol/mg protein); (c) GST activity (nmol/min/mg protein); (d) CAT activity ( $\mu \mathrm{mol} / \mathrm{min} / \mathrm{mg}$ protein). When Kruskal-Wallis was significant, Mann Whitney tests were performed * and $* * *$ show significant differences compared to the corresponding controls at $\mathrm{p}<0.05$ and $\mathrm{p}<0.001$ levels, respectively.

a )

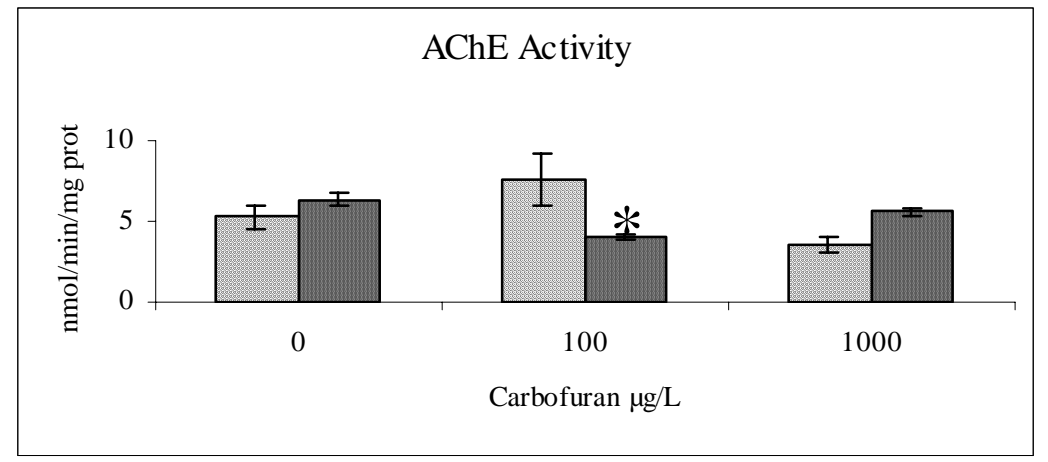

b )

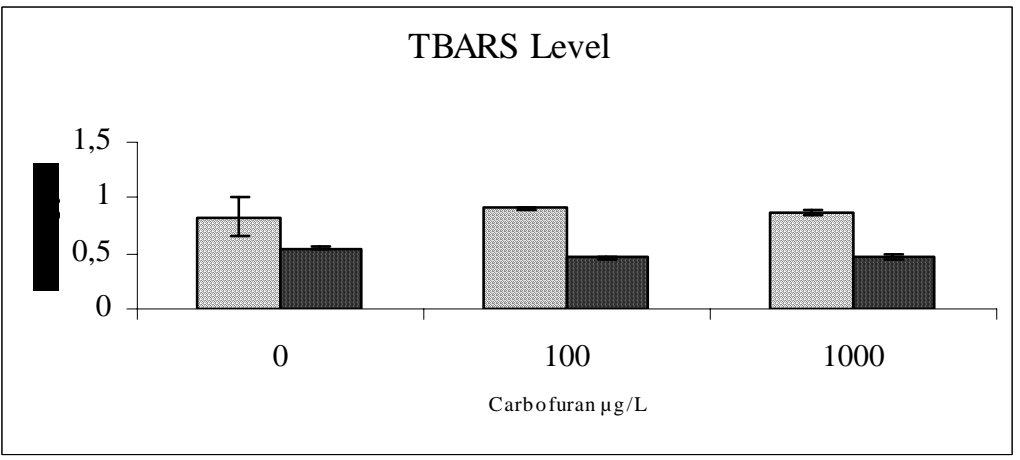

c)

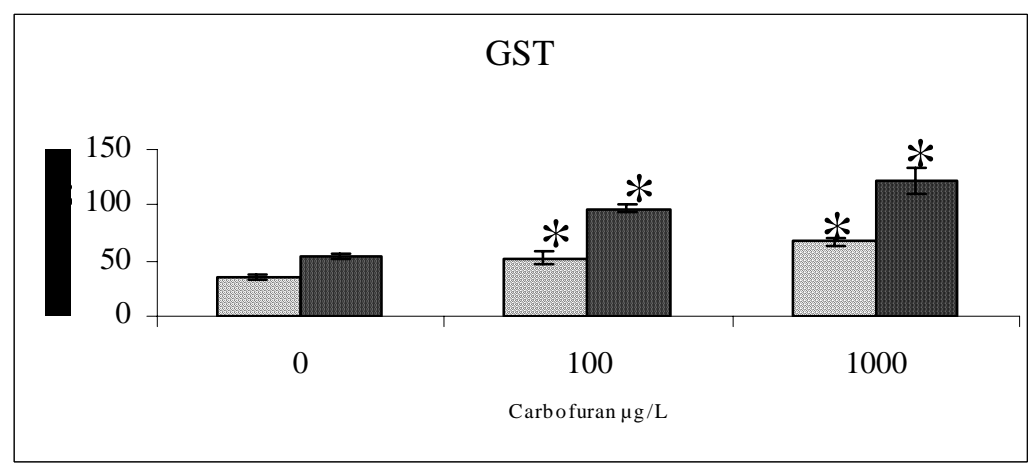

d)

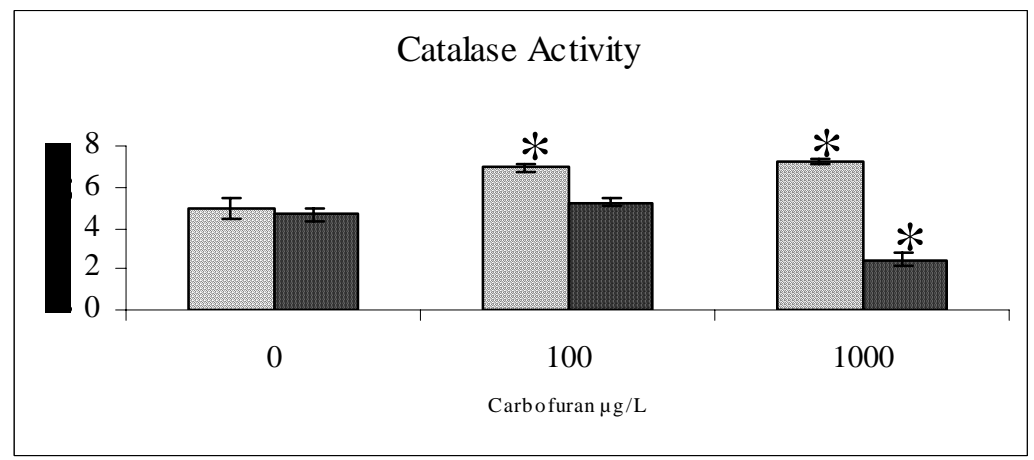




\subsection{Effect of temperature and salinity}

The decrease of AChE activity with salinity found in this work was also observed in the annelid polychaete Nereis diversicolor, under experimental conditions (Scaps and Borot, 2000). The authors reported that salinity had a greater effect on AChE activity than temperature. On the other hand, Forget (1998) showed seasonal variations of AChE activity in the gills of the mussel Mytilus edulis with lower activity during autumn and winter compared to higher levels in summer, whereas no effect of temperature was found in the present experiments performed at $20^{\circ}$ and $25^{\circ} \mathrm{C}$.

The increase of TBARS levels with temperature in the oyster larvae is comparable with the results of Pellerin-Massicotte (1997), who found high levels of TBARS in M. edulis with increasing temperatures.

As regards the influence of environmental parameters on GST activity, Dellali (2001) observed that the salinity does not change this activity in the mussel M. galloprovincialis and the clam Ruditapes decussatus from the Bizerta lagoon. In the mussel M. edulis, GST activity in the gills was at its maximum during winter, when temperature is low (Power and Sheehan, 1996).

No significant correlation between catalase activity and salinity was observed in either the mussel M. galloprovincialis or in the clam R. decussatus (Dellali et al., 2001). However, these authors indicated an increase of catalase activity with temperature, as did Pellerin-Massicotte (1994), who showed the same phenomenon in the mussel M. edulis from the Saint Lawrence River estuary. These results are in good agreement with those reported in this study. 


\subsection{Effect of carbofuran}

The chemical determination demonstrated a very significant loss of carbofuran in the medium which was higher at $1000 \mu \mathrm{g} / \mathrm{L}$ (ca 65\% loss) than at $100 \mu \mathrm{g} / \mathrm{L}$ (ca 45\% loss). This loss could be due to adsorption on to the glass beakers, on the larvae, as well as uptake by the larvae, as evidenced through the observed toxic effects.

Carbofuran is a well-known inhibitor of AChE activity. Bocquené et al. (1995) reported extremely high inhibitory activities of pesticides such as dichlorvos, carbaryl and carbofuran to four marine species, of which the IC50 of carbofuran was $1.5 \times 10^{-8} \mathrm{M}$ for the gill tissue of C. gigas. Such an inhibition of AChE activity was found in the first experiment reported here (unfortunately the actual carbofuran concentrations in the medium could not be measured), although the results were less significant in the second experiment where carbofuran concentrations recovered in the medium were low.

In the first experiment, TBARS levels increased at the highest carbofuran concentration, implying a toxic effect of this contaminant. It is possible that CAT levels were not high enough to prevent lipid peroxidation. This phenomenon was also described for $M$. edulis in Pellerin-Massicotte’s study (1997). GST activity, which can be considered as a part of the antioxidant forces in the cells of aquatic animals (Cossu et al., 1997), did not change. In the same way, Cheung et al. (2002) reported that some less specific antioxidant parameters than CAT activity, such as glutathione (GSH) and GST activity, did appear to show significant induction in response to trace organic contaminants in adult mussels, Perna viridis.

In the second experiment, CAT and GST activities increased whereas TBARS did not. Pellerin-Massicotte (1997) reported that an observed increase of CAT without an increase in MDA (malonedialdehyde, one compound included in TBARS) could be seen as a production of free radicals followed by their removal but without physiological consequences. CAT 
activity measured in larvae from couple A increased from the lowest carbofuran concentration until $1000 \mu \mathrm{g} / \mathrm{L}$. This increase is similar to that of GST activity, implying that protective forces were mobilized against the chemical pollutant. This mobilization appears effective since TBARS levels did not change, as mentioned above.

The effect of carbofuran differs according to the larvae taken into consideration, as a matter of fact, in larvae from couple B CAT activity decreased at $1000 \mu \mathrm{g} / \mathrm{L}$, demonstrating the toxicity of carbofuran which appeared to inhibit CAT. Palace et al. (1996) proposed that organic contaminants which caused oxidative stress could also inhibit the activities of protective enzymatic antioxidants.

The comparison between the two carbofuran experiments shows a more or less pronounced inhibition of AChE activity and an equilibrium between anti-oxidant forces (such as catalase and GST activities) and toxic effects (TBARS levels).

An interesting feature of the results, when the two pairs of adults are considered (in the second experiment with carbofuran), are the different levels of biomarkers measured in the larvae from the two pairs of animals. This may be due to the different physiological status of larvae as shown by the toxicity tests carried out with copper sulphate. As suggested by Stebbing et al. (1980), genetic differences may occur, subsequently causing different biochemical responses to the tested pesticide.

\subsection{Effect of malathion}

The measured malathion concentration in the experimental medium showed a loss of this compound. Nevertheless, the loss is less important than that of carbofuran. The reasons for the loss appeared to be the same as those given for the carbamate. 
The decrease in AChE activity is less than that with carbofuran (especially in the first experiment). According to Bocquené et al. (1995) thiono-type organophophorus compounds are not AChE inhibitors and require metabolic activation to become strong irreversible inhibitors ; in vivo, this activation mainly occurs through the action of mixed-function oxidase enzymes (phase I enzymes) which could not be measured in oyster larvae. After phase I, subsequent reactions generally involve phase II enzyme such as GST. GST activitites were unchanged in the malathion experiment (Fig. 3) suggesting that phase I enzymes were not activated. CAT activity seems to have a protective influence against malathion (at $300 \mu \mathrm{g} / \mathrm{L}$ ), and lipid peroxidation of membranes did not occur (TBARS levels were lower at this concentration).

To conclude, this paper reports the results on some biochemical markers measured in the larvae of bivalve molluscs (and particularly in C. gigas larvae). Few results exist in the literature about biomarkers in bivalve larvae. The results show that the abiotic parameters temperature and salinity may influence the biochemical responses of larvae. The effect of the two pesticides, carbofuran and malathion, caused an inhibition of AChE activity in most instances. These pollutants seem to produce an oxidative stress (measured by TBARS levels), which is counteracted by CAT or GST activities. Interestingly, it was also noted that when two adult couples are induced to spawn, the larvae from the couples present different levels of biomarkers. It seems therefore that for a good control of quality of a bioassy dealing with the impact of pollutants on larvae, the variability inter individuals has to be decreased. Attempts are now made to use C. gigas larvae’s as bioindicators of pollution, especially by Coastal and Marine biotechnologies, Ltd, (http: //www.nerc.ac.uk) which developed a new procedure using a pool of larvae carefully frozen and keeping their characteristics. In the future, the authors will try to use this process, which helps combat marine pollution. 


\section{Acknowledgments}

This work was funded by the French Ministry of Environment (program PNETOX 2001

D4E -SRP).

\section{References}

Bengtson, D.A., Henshel, D.S., 1996. Environmental toxicology and risk assessment: Biomarkers and risk assessment- vol. V. ASTM, STP 1306, West Conshohocken, PA.

Bocquené, G., Bellanger, C., Cadiou, Y., Galgani, F., 1995. Joint action of combinations of pollutants on the acetylcholinesterase activity of several marine species. Ecotoxicology 4, 266-279.

Bradford, M., 1976. A rapid and sensitive method for the quantification of microgram quantities of protein utilizing the principle of protein-dye blinding. Anal. Biochem. 72, 248-254.

Buege, J.A., Aust, S.D., 1978. Microsomal lipid peroxidation. Meth. Enzymol. 52, 302-310.

Cajaraville, M.P., Bebianno, M.J., Blasco, J., Porte, C., Sarasquete, C., Viarengo, A., 2000. The use of biomarkers to assess the impact of pollution in coastal environments of the Iberian Peninsula: a practical approach. Sci. Total Environ. 247, 295-311.

Cheung, C.C.C; Zheng, G.J.,Lam, P.K.S., Richardson, B.J., 2002. Relationships between tissue concentrations of chlorinated hydrocarbons (polychlorinated biphenyls and chlorinated pesticides) and antioxidative responses of marine mussels, Perna viridis. Mar. Pollut. Bull. 45, 181-191.

Clairbone, A., 1985. Catalase activity; In: Greenwald, R.A. (Ed), Handbook of methods for oxygen radical research. CRC Press, Boca Raton, FL, pp; 283-284.

Cossu, A., Doyotte, A., Jacquin, M.C., Vasseur, P., 1997. Biomarqueurs du stress oxydant chez les animaux aquatiques. In: Lagadic, L., Caquet, T., Amiard, J.C., Ramade, F. (Eds), Biomarqueurs en écotoxicologie. Aspects fondamentaux. Masson, Paris, pp. 149-163.

Csallany, A.S., Der Guan, M., Manwaring, J.D., Addis, P.B., 1984. Free malondialdehyde determination in tissues by high-performance liquid chromatography. Anal. Biochem. 142, 277-283.

de Lafontaine, Y., Gagné, F., Blaise, C., Costan, G., Gagnon, P., Chan, H.M., 2000. Biomarkers in zebra mussels (Dreissena polymorpha) for the assessment and monitoring of water quality of the St Lawrence River (Canada). Aquat. Toxicol. 50, 51-71.

Dellali, M., 2001. Utilisation d'indicateurs microbiologiques et biochimiques chez deux bivalves (Ruditapes decussatus et Mytilus galloprovincialis) dans la biosurveillance de la lagune de Bizerte: Validation de certains biomarqueurs. Thèse de Doctorat en Sciences Biologiques, Faculté des Sciences de Bizerte, Tunisie.

Dellali, M., Roméo, M., Aissa, P., 2001. Suivi de l'activité catalase des moules et des palourdes originaires de la lagune de Bizerte. Oceanol. Acta 24, 263-271.

Ellman, G.L., Courtney, K.D., Andre, J.R.V., Featherstone, R.M., 1961. A new and rapid colorimetric determination of acetylcholinesterase activity. Biochem. Pharmacol. 7, 88-95.

Escartin, E., Porte, C., 1997. The use of cholinesterase and carboxylesterase activities from Mytilus galloprovincialis in pollution monitoring. Environ. Toxicol. Chem. 16, 2090-2095. 
Fitzpatrick, P.J., O’Hallaran, J., Sheehan, D., Walsh, A.R., 1997. Assessment of a glutathione $S$-transferase and related proteins in the gill and digestive gland of Mytilus edulis (L), as potential organic pollution biomarkers. Biomarkers 2, 51-56.

Forget, J., 1998. Impact neurotoxique de contaminants (pesticides et métaux) sur un crustacé marin Tigriopus brevicornis (Müller). Caractérisation de la cholinestérase et application à la surveillance des effets des polluants sur l'environnement marin. Thèse de Doctorat, Université Paris 6.

Galgani, F., Bocquené, G., 1989. A method for routine detection of organophosphates and carbamates in sea water. Environ. Technol. Lett. 10, 311-322.

Galgani, F., Bocquené, G., 1991. Semi-automated colorimetric and enzymatic assays for aquatic organisms using microplate readers. Wat. Res. 25, 147-150.

Geffard, A., Geffard, O., His, E., Amiard, J.C., 2002. Relationships between metal bioaccumulation and metallothionein levels in larvae of Mytilus galloprovincialis exposed to contaminated estuarine sediment elutriate. Mar. Ecol. Prog. Ser. 233, 131-142.

Granmö, A., 1972. Development and growth of eggs and larvae of Mytilus edulis exposed to a linear dodecylbenzenesulphonate, LAS. Mar. Biol. 15, 356-358.

Habig, W.H., Pabst, M.J., Jakobi, W.B., 1974. Glutathione S-transferases: The first enzymatic step in mercapturic acid formation. J. Biol. Chem. 249, 7130-7139.

His, E., Seaman, M.N.L., Beiras, R., 1997. A simplification of the bivalve embryogenesis and larval development bioassay method for water quality assessment. Wat. Res. 31, 351-355.

His, E., Beiras, R., Seaman, M.N.L., 1999a. The assessment of Marine Pollution. Bioassays with Bivalve Embryos and Larvae. Adv. Mar. Biol. 37, 1-178.

His, E., Heyvang, I., Geffard, O., Montaudoin, X., 1999b. A comparison between oyster (Crassostrea gigas) and sea urchin (Paracentrotus lividus) larval bioassays for toxicological studies. Wat. Res. 33, 1706-1718.

Hoarau, P., Gnassia-Barelli, M., Roméo, M., Girard, J.P., 2001. Differential induction of GST in the clam Ruditapes decussatus exposed to organic compounds. Environ. Toxicol. Chem. 20, 523-529.

Knight, J.A., Pieper, R.K., McClellan, L., 1988. Specificity of the thiobarbituric acid reaction: its use in studies of lipid peroxidation. Clin. Chem. 34, 2433-2438.

Mc Carthy, J.F., Shugart, L., 1990. Biomarkers of Environmental Contamination. Lewis Publishers: Boca Raton, FL.

Mora, P., Michel, X., Narbonne, J.F., 1999. Cholinesterase activity as potential biomarker in two bivalves. Environ. Toxicol. Pharmacol. 7, 253-260.

Palace, V.P., Klaverkamp, J.F., Lockhart, W.L., Metner, D.A., Muir, D.C.G., Brown, S.B., 1996. Mixed-function oxidase enzyme activity and oxidative stress in Lake Trout (Salvelinus namaycush) exposed to 3,3',4,4',5-pentachlorobiphenyl PCB-126. Environ. Toxicol. Chem. 15, 955-960.

Pavicic, J., Skreblin, M., Kregar, I., Tusek-Znidaric, M., Stegnar, P., 1985. Formation of inducible Cd-binding proteins in selected organs and developmental stages of Mytilus galloprovincialis. VII Journées Etud. Pollut. C. I. E. S. M., Lucerne, 1984, pp. 699-705.

Pavicic, J., Skreblin, M., Kregar, I., Tusek-Znidaric, M., Stegnar, P., 1994. Embryo-larval tolerance of Mytilus galloprovincialis, exposed to the elevated sea water metal concentrations-1. Toxic effects of $\mathrm{Cd}, \mathrm{Zn}$ and $\mathrm{Hg}$ in relation to the metallothionein level. Comp. Biochem. Physiol. 107C, 249-257.

Pellerin-Massicotte, J., 1994. Oxidative processes as indicators of chemical stress in marine bivalves. J. Aquat. Ecosys. Health 3, 101-111.

Pellerin-Massicotte, J., 1997. Influence of elevated temperature and air-exposure on MDA levels and catalase activities in digestive glands of the blue mussel (Mytilus edulis L.). J. Rech. Océanogr. 22, 91-98. 
Pluta, H.J., 1993. Investigations on biotransformation mixed function oxygenase activities in fish liver. In: Braunbeck, T., Hanke, W., Segner, H. (Eds), Fish Ecotoxicology and Ecophysiology. VCH Weinheim, pp.13-33.

Power, A., Sheehan, D., 1996. Seasonal variation in the antioxidant defense systems of gill and digestive gland of the blue mussel, Mytilus edulis. Comp. Biochem. Physiol. 114C, 99103.

Quiniou, F., Judas, A., Le Suer-André, E., 1997. Toxicité potentielle des eaux et des sédiments des principaux estuaires de la rade de Brest évaluée par deux bio-essais. Ann. Inst. Océanogr. 73, 35-48.

Ringwood, A.H., Brouwer, M., 1995. Patterns of metalloprotein expression in oyster embryos. Mar. Environ. Res. 39, 101-105.

Roesijadi, G., Hansen, K.M., Unger, M.E., 1996. Cadmium-induced metallothionein expression during embryonic and early larval development of the Mollusc Crassostrea virginica. Toxicol. Appl. Pharmacol. 140, 356-363.

Roy, S., Lindström-Seppä, P., Hänninen, O., 1996. Integrative approach to aquatic environment biomonitoring. In: Richardson, M. (Ed.), Environmental Xenobiotics. Taylor and Francis, London, pp. 123-142.

Scaps, P., Borot, O., 2000. Acetylcholinesterase activity of the polychaete Nereis diversicolor effects of temperature and salinity. Comp. Biochem. Physiol. 125C , 377-383.

Stebbing, A., Akesson, B., Calabrese, A., Gentile, J.H., Jensen, A., Lloyd, R., 1980. The role of bioassays in marine pollution monitoring. Rapp. P.-V. Réuni. Cons. Int. Explor. Mer 179, 322-332.

Stegeman, J.J., Brouwer, M., Di Giulio, R.T., Förlin, L., Fowler, B.A., Sanders, B.M., Van Veld P.A., 1992. Molecular responses to environmental contamination: enzyme and protein systems as indicators of chemical exposure and effect. In: Huggett, R.J., Kimerle, R.A., Merhle, P.M., Bergman, H.L. (Eds), Biomarkers: biochemical, physiological and histological markers of anthropogenic stress. A special publication of SETAC, Lewis Publishers, Chelsea, MI, pp. 235-335.

Stegeman, J.J., Hahn, M.E., 1994. Biochemistry and molecular biology of monoxygenases : current perspectives on forms, functions, and regulation of cytochrome P450 in aquatic species. In: Ostrander, G.K., Malins, D. (Eds), Aquatic Toxicology: Molecular, Biochemical and Cellular Perspectives. Lewis Publishers, Boca Raton, FL, pp.87-206

Stien, X., Percic, P., Gnassia-Barelli, M., Roméo, M., Lafaurie, M., 1998. Evaluation of different biomarkers in caged fish and mussels to assess the quality of waters in the bay of Cannes (Côte d’Azur), S.E. France. Environ. Pollut. 99, 339-345.

Van der Oost, R., Goksøyr, A., Celander, M., Heida, H., Vermeulen, N.P.E., 1996. Biomonitoring of aquatic pollution with feral eel (Anguilla anguilla): II. Biomarkers: pollution-induced biochemical responses. Aquat. Toxicol. 36, 189-222.

Wiseley, B., Blick, R., 1967. Mortality of marine invertebrate larvae in mercury, copper and zinc solutions. Aust. J. Mar. Freshw. Res. 18, 63-72. 
